\title{
Prevalence of asymptomatic hepatitis B virus and hepatitis $C$ virus infections in patients with maintenance hemodialysis of a tertiary care hospital in western Maharashtra
}

\author{
Santosh Shankar Patil ${ }^{1, *}$, Bipin Munjappa², Shubhangi A. Gadgil ${ }^{3}$, Amit Gadve ${ }^{4}$ \\ ${ }^{\mathbf{1}}$ Associate Professor, ${ }^{\mathbf{2}}$ Professor, ${ }^{3}$ Professor and Head, ${ }^{\mathbf{4}}$ Assistant Professor, ${ }^{\mathbf{1}, \mathbf{3}}$ Dept. of Microbiology, ${ }^{\mathbf{2}, \mathbf{4}}$ Dept. of Nephrology, \\ Bharati Vidyapeeth Deemed University, Medical College, Sangli, Maharashtra, India \\ *Corresponding Author: \\ Email: drsantoshpatil21@gmail.com
}

Received: $8^{\text {th }}$ May, 2018

Accepted: $29^{\text {th }}$ June, 2018

\begin{abstract}
Introduction: Patients on Maintenance Hemodialysis (HD) are at high risk of viral hepatitis due to blood transfusion, prolonged vascular access, exposure to infected patients and contaminated equipments etc. Knowledge of the prevalence of such infections is very important to access magnitude of the problem because these infections play important role in the morbidity and mortality of hemodialysis (HD) patients.

Aim and Objectives: This study was done to determine the prevalence of Hepatitis B virus (HBV) and Hepatitis C virus (HCV) infections in patients on hemodialysis at our tertiary care hospital of Western Maharashtra.

Materials and Methods: Settings and Design: Hospital based cross sectional study was conducted for six months in HD unit at our tertiary care hospital. All patients $(\mathrm{n}=135)$ were screened for Hepatitis B surface antigen and antibodies to HCV (anti-HCV). Prevalence, age and sex wise distribution as well as risk factors for transmission of these infections were observed.

Results: Total 135 HD patients were screened for presence of HBV and HCV infections. Of these, 39 (28.9\%), 20 (14.8\%), 6 (4.4\%) were found to be having HCV, HBV and Dual HBV and HCV infection respectively.

Conclusions: HCV was the most prevalent among HD patients than HBV. History of multiple blood transfusions, HD outside center or longer duration of HD were all important risk factor noted for high prevalence of sero-positivity for HBV and/or HCV. Strict adherence to universal precautions careful attention to hygiene and strict sterilization of dialysis machines are important to prevent further transmission of these viruses.
\end{abstract}

Keywords: Hemodialysis, HBsAg, Anti HCV antibodies, Hepatitis.

\section{Introduction}

Dysfunction of the kidneys is now a global pandemic and occurs at any stage of life with varying degree of severity. Patients suffering with End Stage Renal Disease (ESRD) are largely dependent on Hemodialysis (HD). Survival rate of patients with Chronic Renal Failure (CRF) has significantly increased due to widespread access to dialysis. ${ }^{1}$ Although, HD is an important modality of therapy for CRF patients, it may also lead to the transmission of some blood borne infections. Hepatitis B Virus (HBV) and Hepatitis C Virus (HCV) infections are the most common infections among patients with maintenance hemodialysis. ${ }^{2}$

There are several reasons because of which, patients on maintenance HD are always at high risk of acquiring such types of infections. Repeated transfusion of blood and blood products, contaminated equipments, cross contamination from the dialysis circuits, lack of universal and safety precautions, etc may lead to high possibility of exposure to infected patients. ${ }^{3}$ Not only these but poor immunological status due to renal impairment also predispose these patients to infections. ${ }^{4}$ Infections due to these pathogens ultimately lead to increased morbidity and mortality in HD patients and it becomes challengeable task in the management of these patients in renal dialysis units.
The prevalence of HBV and HCV vary widely across countries, ranging from $1 \%$ in UK to more than $90 \%$ in Eastern Europe. ${ }^{5}$ Even in India wide ranges of prevalence rate of HBV (3.4 to 43\%) and HCV (4.3 to 45.2\%) infections in HD patients have been reported. ${ }^{4,6}$ Dual infections due to HBV and HCV is yet another important problem among patients with long term HD which leads to more severe liver disease and responsible for increase mortality rate. ${ }^{7}$

Knowledge of the prevalence of such infections is very important to access magnitude of the problem and to take all preventive measures to decrease the disease burden. This will ultimately improve morbidity and mortality profile of HD patients. Therefore, in the present study we planned to assess the prevalence of $\mathrm{HBV}$ and $\mathrm{HCV}$ in HD patients of our tertiary care hospital.

\section{Materials and Methods}

Study Design: Prospective, cross sectional study. Settings: A study was carried out in the Department of Microbiology in collaboration with Department of Nephrology in our hospital. Study protocol was approved by the Institutional Ethics Committee.

Inclusion Criteria: Only CRF patients on maintenance hemodialysis were included in the present study with their written informed consent. 
Study Size: A total of 135 patients on hemodialysis, irrespective of their age and sex were studied over a period of six months.

Data Source: A preformed proforma was filled with all necessary information along with details of clinical examinations and history. Clinical history included history of multiple blood transfusions, transplantation history, vaccination, duration of $\mathrm{HD}$, history of hypertension, diabetes mellitus etc.

Sample Collection and Processing: With all aseptic precautions, $5 \mathrm{ml}$ of blood was collected in plain sterile vacuteiner. Separated serum was collected in sterile tubes and was used for further study. Anti HCV antibodies were detected by using $3^{\text {rd }}$ generation ELISA (HCV MICROELISA Kit by, J Mitra Pvt. Limited, New Delhi). HBsAg was detected by using $3^{\text {rd }}$ generation ELISA kit. (Hepelisa kit by, J Mitra Pvt. Limited, New Delhi). All the tests were performed in accordance with manufacturer's instructions with controls.

Results were collected after reading absorbance by Biorad ELISA reader with dual filters at $450 \mathrm{~nm}$ and $630 \mathrm{~nm}$, immediately after adding stopping solution. Positive samples were retested and negative samples were randomly reexamined for confirmation.

Variables: Age, Sex and duration of HD

Bias: Reporting bias

Statistical Methods: Relevant statistics were applied. Simple tabulations and proportions were calculated.

\section{Results}

Total 135 patients participated in the study. Out of this $104(77 \%)$ were males and $31(23 \%)$ were females. Male to female ratio was 3.3:1. Most of the patients were between 21 to 60 years age group and mean age was 46.16 years. Total 35 (26\%) patients had history of HD outside the center and $84(62.2 \%)$ patients gave history of blood transfusions. There were 94 (69.6\%) patients on HD for more than one year and 41(30.4\%) were on dialysis for less than a year (Table 1). Hypertensive nephropathy with CRF was found to be the commonest cause for HD with incidence rate of 47 (34.9\%) followed by diabetes mellitus (DM) nephropathy with incidence rate of $38(28.1 \%)$ whereas $28(20.7 \%)$ patients were with non specific cause for HD (Table 2). Of the total 135 patients, 39 (28.9\%) were $\mathrm{HCV}$ infected, 20 (14.8\%) patients were with HBV and $6(4.4 \%)$ were suffering with dual infection of $\mathrm{HCV}$ and HBV. However, 70 (51.9\%) patients were remained uninfected during our study period (Fig. 1). Total $51(49 \%)$ male patients were positive for HBV, HCV or both. Whereas, 14 (45\%) female patients were positive for either HBV or HCV and there was no case of dual infection found. Prevalence of HBV and HCV infections among male patients was $16(15.4 \%)$ and 29 (27.9\%) respectively. While in females it was 4 $(12.9 \%)$ and $10 \quad(32.2 \%)$ respectively. Maximum numbers of cases were belonging to the age group of 41 to 60 years and there was only one case from age group below 20 years. Of the total 65 sero-positive cases, 26 (40\%) were belongs to 41 to 60 years age group and 25 $(38.4 \%)$ were in the age group 21 to 40 years. There were six cases with dual infection out of which five were from age group more than 60 years. (Table 3)Total $21 / 84$ (25\%) patients who gave history of blood transfusion, were found to be sero-positive to $\mathrm{HBV}$ and/or HCV. Whereas, 17/35 (48.5\%) patients who gave history of HD outside our center were seropositive for HBV, HCV or both. When duration of HD was studied, we observed that $35.1 \%$ patients were on HD for more than a year and $12.1 \%$ were so for less than a year. (Table 1). Of the total 135 patients, 71 (52.6\%) were vaccinated before commencing $\mathrm{HD}, 50$ (37\%) were vaccinated at the time of $\mathrm{HD}$, and 14 (10.4\%) were not yet vaccinated against HBV.

Table 1: Demographic profile of patients on maintenance hemodialysis

\begin{tabular}{|c|c|c|c|}
\hline \multicolumn{2}{|l|}{ Parameter } & $\begin{array}{c}\text { Total patients } \\
(n=135)\end{array}$ & Sero-positive patients \\
\hline \multicolumn{2}{|l|}{ Patients on HD } & 135 & $65(48.1 \%)$ \\
\hline \multicolumn{2}{|l|}{ Males } & $104(77 \%)$ & $51(49 \%)$ \\
\hline \multicolumn{2}{|l|}{ Females } & $31(23 \%)$ & $14(45 \%)$ \\
\hline \multicolumn{2}{|c|}{ History of HD outside center } & $35(26 \%)$ & $17(48.5 \%)$ \\
\hline \multicolumn{2}{|c|}{ History of Blood Transfusions } & $84(62.2 \%)$ & $21(25 \%)$ \\
\hline \multirow[t]{2}{*}{ Duration of HD } & >one year & $94(69.6 \%)$ & $33(35.1 \%)$ \\
\hline & <one year & $41(30.4 \%)$ & $5(12.1 \%)$ \\
\hline Male:Female ratio & $3.3: 1^{\prime}$ & - & - \\
\hline Average age & $\begin{array}{c}\text { 46.1 years } \\
(19-80 \text { years) }\end{array}$ & - & - \\
\hline
\end{tabular}


Table 2: Underlying diseases in patients of CRF undergoing maintenance hemodialysis

\begin{tabular}{|l|c|}
\hline \multicolumn{1}{|c|}{ Underlying Diseases } & Number of patients \\
\hline Hypertension & $47(34.9 \%)$ \\
\hline Diabetes mellitus & $38(28.1 \%)$ \\
\hline Chronic glomerulonephritis & $13(9.6 \%)$ \\
\hline Obstructive nephropathy & $03(2.2 \%)$ \\
\hline Use of NSAID & $02(1.5 \%)$ \\
\hline Urolithiasis & $04(3 \%)$ \\
\hline
\end{tabular}

Table 3: Frequency age distribution of HBV and/or HCV sero-positive patients on maintenance hemodialysis

\begin{tabular}{|c|c|c|c|c|c|c|c|c|c|}
\hline \multirow{2}{*}{$\begin{array}{l}\text { Sex } \\
\text { Age }\end{array}$} & \multicolumn{3}{|c|}{$\begin{array}{c}\text { Male }(n=51 / 104) \\
(49 \%)\end{array}$} & \multirow{2}{*}{$\begin{array}{l}\text { Total } \\
\text { Male }\end{array}$} & \multicolumn{3}{|c|}{$\begin{array}{c}\text { Female }(n=14 / 31) \\
(45.1 \%)\end{array}$} & \multirow{2}{*}{$\begin{array}{l}\text { Total } \\
\text { Female }\end{array}$} & \multirow{2}{*}{$\begin{array}{l}\text { Total } \\
n=65 \\
(\%)\end{array}$} \\
\hline & $\begin{array}{c}\text { HBV } \\
\text { infected }\end{array}$ & $\begin{array}{c}\text { HCV } \\
\text { infected }\end{array}$ & $\begin{array}{c}\text { Dual } \\
\text { infected }\end{array}$ & & $\begin{array}{c}\text { HBV } \\
\text { infected }\end{array}$ & $\begin{array}{c}\mathrm{HCV} \\
\text { infected }\end{array}$ & $\begin{array}{c}\text { Dual } \\
\text { infected }\end{array}$ & & \\
\hline $0-20$ & - & 1 & - & 1 & - & - & - & - & $\begin{array}{c}1 \\
(1.5)\end{array}$ \\
\hline $21-40$ & 6 & 11 & - & 17 & 1 & 7 & - & 8 & $\begin{array}{c}25 \\
(38.5)\end{array}$ \\
\hline $41-60$ & 8 & 12 & 1 & 21 & 2 & 3 & - & 5 & $\begin{array}{c}26 \\
(40)\end{array}$ \\
\hline$\geq 61$ & 2 & 5 & 5 & 12 & 1 & - & - & 1 & $\begin{array}{c}13 \\
(20)\end{array}$ \\
\hline Total $(\%)$ & $\begin{array}{c}16 \\
(15.4)\end{array}$ & $29(27.9)$ & $\begin{array}{c}6 \\
(5.7)\end{array}$ & $\begin{array}{c}51 \\
(49)\end{array}$ & $\begin{array}{c}4 \\
(12.9)\end{array}$ & $\begin{array}{c}10 \\
(32.2)\end{array}$ & - & $\begin{array}{c}14 \\
(45.1)\end{array}$ & $\begin{array}{c}65 \\
(100)\end{array}$ \\
\hline
\end{tabular}

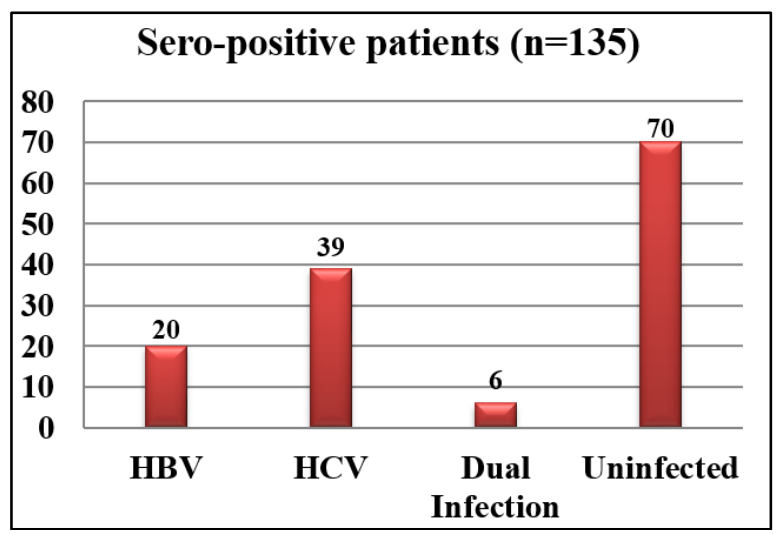

Fig. 1: Hepatitis $B$ virus and/or hepatitis $C$ virus infections in patients on maintenance hemodialysis

\section{Discussion}

In India the $\mathrm{HBV}$ and $\mathrm{HCV}$ prevalence rate in general population is around $4.7 \%$ and $1.85 \%$ respectively. ${ }^{3}$ But in case of HD patients the prevalence rate is varies from center to center, region to region and country to country. ${ }^{3}$

In our study anti-HCV antibodies were found in $28.8 \%$ of patients. This is lower than studies conducted by Rawat et al. (36.75\%), Mittal et al. (30.5\%), Chandra et al (46\%), and higher than Jasuja et al. (27.7\%) and Subramanian et al. (2.7\%)., ${ }^{3,79-11}$

Worldwide prevalence rate ranging from $4-15 \%$ for HBsAg in HD patients has been reported, whereas, in India it ranges from $3.4 \%$ to $45 \% .4$.,12 We report $14.8 \%$ HBV positivity among HD patients which in agreement with the study conducted by Mittal et al (10.2\%), Bhaumika et al (12.1\%). ${ }^{7,13}$ However, Rawat et al reported 7\% HBV positivity and Saravanan et al reported $33.5 \%$ positivity in their studies. ${ }^{3,14}$

Since, HBV and HCV share common mode of transmission, we looked for dual infections of HBV and $\mathrm{HCV}$ in HD patients. We found $6(4.4 \%)$ of patients were infected with HBV and HCV both. Hung et al reported $30.4 \%$ of $\mathrm{HBV}$ and $\mathrm{HCV}$ dual infection in HD patients. ${ }^{15}$ Reddey et al. ${ }^{16}$ reported $3.7 \%$ and Saravanan et al. ${ }^{14}$ reported $5.9 \%$ prevalence rate of dual infection in their respective studies.

Previous studies reported the prevalence of HBV, $\mathrm{HCV}$, and Dual infection as $2.6 \%, 31.1 \%$ and $1.2 \%,{ }^{8}$ $7 \%, 46 \%$, and $3.7 \%,{ }^{13} 1.5 \%, 33.5 \%$ and $0.5 \%,{ }^{17} 11 \%$, $30 \%$ and $3 \%,{ }^{18}$ respectively.

In the present study prevalence of HCV was high among HD patients. Our hospital is tertiary care hospital where patients are referred from different part of the district and neighboring states as well. Most of the patients were with previous history of $\mathrm{HD}$ at different centers and history of blood transfusions for multiple times.

We report high prevalence of HCV $(28.8 \%)$ than HBV (14.8\%). previous studies support our results which clearly indicate that $\mathrm{HCV}$ is more prevalent than HBV in HD patients. ${ }^{8,13,17,18}$

$\mathrm{HCV}$ as well as HBV infections were more frequently encountered among the age group of $41-60$ years, followed by 21-40 years, indicating pattern of infectivity of HBV and HCV was mainly towards older age group. There was no significant difference noted in 
the prevalence rate of $\mathrm{HBV}$ or $\mathrm{HCV}$ infections in any particular age or sex. However, dual infections were seen only in the age group of more than 60 years and all were male patients. Other studies also reported high prevalence of sero-positivity in older age group.,19 There is no clear statement in the previous studies about variation in predisposing age or sex of HD patients for infection. ${ }^{19}$

Patient visits multiple centers for variety of reasons like travelling, emergency, surgery, or as per their convenience. Patients with history of HD at different centers showed $48.5 \%$ sero- positivity. This reflects differences in adherence to infection control policies in individual centers.

Total $62.2 \%$ patients were having history of blood transfusion, out of which $25 \%$ were sero-positive for HBV and/or HCV. Prevention of nosocomial transmission is of vital importance. Antiviral treatment for $\mathrm{HCV}$ and $\mathrm{HBV}$ infections is highly expensive and not readily available. Inadequate screening of blood and blood products as well as screening procedures used are most commonly responsible for transmission of these viruses during blood transfusion. According to AlHegami et al. ${ }^{5}$ and Alashek et al. ${ }^{8}$ history of blood transfusion and number of transfusions is strongly associated with $\mathrm{HBV}$ and $\mathrm{HCV}$ infection. We used 3rd generation ELISA kits for screening of $\mathrm{HCV}$ with sensitive $100 \%$ and specificity of $97.4 \%$ and also for HBV with sensitive and specificity of $100 \%$.

We report $35.1 \%$ sero-positivity among the patients on HD more than one year and it was $12.1 \%$ in patients who were on HD less than one year. Patients on longer duration of $\mathrm{HD}$ are at high risk of acquiring infections. ${ }^{5,8}$

Hepatitis B vaccination is recommended for all susceptible chronic hemodialysis patients. Early vaccination and regular monitoring of the titers is necessary in the high risk group patients to maintain sero-protective level against HBV. ${ }^{4}$

Lack of strict adherence to universal precautions, sharing of articles, instruments, medicines etc among HD patients have been reported the important mode of transmission of these viruses. ${ }^{5,8,19}$ To prevent transmission of these infections, utmost priority should be given for wearing and changing gloves and gowns between patients, decontamination of equipment circuits and surfaces after treatment and no sharing of instruments or medications among the HD patients. Previous studies showed that spread of these infections is declined dramatically when infected patients were treated with dedicated HD unit. ${ }^{5,19}$

\section{Conclusion}

Chronic CRF cases are at high risk of viral hepatitis caused by HCV and HBV. HCV was the most prevalent among HD patients. History of multiple blood transfusions, HD outside center or longer duration of HD were all important risk factor noted for high prevalence of seropositivity for $\mathrm{HBV}$ and/or $\mathrm{HCV}$. There was no specific correlation with age and sex among the positive patients. High prevalence of asymptomatic $\mathrm{HCV}$ and $\mathrm{HBV}$ infections indicates routine screening of HD patients for HCV and HBV, preferably using serological methods. This will helpful to prevent further transmission of viruses as well as to reduce morbidity and mortality rate of the patients on maintenance dialysis.

\section{References}

1. Ali MS, Moftah HS, Moftah SA. Hepatitis B Virus and Hepatitis C Virus in Hemodialysis Patients: A Prevalence Study from Dialysis Centers in El-Beyda and AlmarjLibya. Asian Journal of Biology. 2017;2(2):1-5. DOI: 10.9734/AJOB/2017/31912.

2. Saha D, Agarwal SK. Hepatitis and HIV infection during haemodialysis. J Indian Med Assoc. 2001;99(4):194-9. 203, 213.

3. Rawat N, Mathur N, Rawat K, Mathur M, Chauhan N, Kakkar Ret al. Prevalence of hepatitis B, hepatitis C and human immunodeficiency virus infection among haemodialysis patients in a tertiary health care centre of Western Rajasthan. Int J Med Sci Public Health. 2017;6(4):724-7. DOI: 10.5455/ijmsph.2017.1057824112016.

4. Perumal A, Ratnam PV, Nair S, Anitha P, Illangovan V, Kanungo R. Seroprevalence of hepatitis B and C in patients on hemodialysis and their antibody response to hepatitis B vaccination. J Curr Res Sci Med. 2016;2(1):20-3. DOI: 10.4103/2455-3069.184119.

5. Al-Hegami MA, Al-Mamari A, Al-Kadasse AS, AlGasha'a FAS, Al-Hag S, Al-Hegami AAS. Prevalence and risk factors of hepatitis $\mathrm{b}$ and hepatitis $\mathrm{c}$ virus infections among patients with chronic renal failure in Zabeed City, Yemen Republic. Open J Medical Microbiology. 2015;5:136-42.

6. Chawla NS, Sajiv CT, Pawar G, Pawar B. Hepatitis B and $\mathrm{C}$ virus infections associated with renal replacement therapy in patients with end stage renal disease in a tertiary care hospital in India-prevalence, risk factors and outcome. Indian J Nephrol. 2005;15(4):205-13.

7. Mittal G, Gupta P, Thakuria B, Mukhiya GK, Mittal M. Profile of hepatitis B virus, hepatitis C virus, hepatitis D virus and human immunodeficiency virus infections in hemodialysis patients of a tertiary care hospital in Uttarakhand. J Clin Exp Hepatol. 2013;3(1):24-8. https://doi.org/10.1016/j.jceh.2013.02.003.

8. Alashek WA, McIntyre CW, Taal MW. Hepatitis B and C infection in haemodialysis patients in Libya: Prevalence, incidence and risk factors. BMC Infect Dis. 2012;12(1):265-72. https://doi.org/10.1186/14712334-12-265.

9. Chandra M, Khaja MN, Hussain MM, Poduri CD, Farees N, Habeeb MA, et al. Prevalence of hepatitis B and hepatitis $\mathrm{C}$ viral infections in Indian patients with chronic renal failure. Intervirology. 2004;47(6):374-6. https://doi.org/10.1159/000080883.

10. Jasuja S, Gupta AK, Choudhry R, Kher V, Aggarwal DK, Mishra A, Agarwal M, Sarin A, Mishra MK, Raina V. Prevalence and associations of hepatitis $\mathrm{C}$ viremia in hemodialysis patients at a tertiary care hospital. Indian J Nephrol. 2009;19(2):62-7. doi: 10.4103/09714065.53324 .

11. Subramanian GP, Vegad MM, Vadsmiya MG, Murawala SM, Patel FV. Seroprevalence of hepatitis $\mathrm{C}$ in renal 
failure patients on maintenance hemodialysis - Study in a tertiary care hospital - Western India. Int J Med Sci Public Health. 2016;5(4):678-80. DOI: 10.5455/ijmsph.2016.22072015109.

12. Souza K.P., Luz J.A., Teles S.A. Hepatitis B and C in the hemodialysis unit of Tocantins, Brazil: serological and molecular profiles. Mem Inst Oswaldo Cruz. 2003;98(5):599603.http://dx.doi.org/10.1590/S007402762003000500003.

13. Bhaumik P, Debnath K. Prevalence of hepatitis B and C among haemodialysis patients of Tripura, India. Euroasian J Hepato Gastroenterol. 2012;2(1):10-3.

14. Saravanan S, Velu V, Nandakumar S, Madhavan V, Shanmugasundaram U, Murugavel KG, et al. Hepatitis B virus and hepatitis $\mathrm{C}$ virus dual infection among patients with chronic liver disease. J Microbiol Immunol Infect. 2009;42(2): 122-8.

15. Hung KY, Chen WY, Yang CS, Lee SH, Wu DJ. Hepatitis B and Hepatitis C in haemodialysis patients. Dial Transplant. 1995;24(3):135-9.

16. Reddy GA, Dakshinamurthy KV, Neelaprasad P, Gangadhar T, Lakshmi V. Prevalence of HBV and HCV dual infection in patients on haemodialysis. Indian $\mathrm{J} \mathrm{Med}$ Microbiol. 2005;23(1):41-3.

17. Malhotra R, Soin D, Grover P, Galhotra S, Khutan H, Kaur N. Hepatitis B virus and hepatitis C virus co- infection in hemodialysis patients: A retrospective study from a tertiary care hospital of North India. J Nat Sci Biol Med. 2016;7(1):72-4. doi: 10.4103/0976-9668.175076.

18. Jain $P$, Nijhawan $S$. Occult hepatitis $C$ virus infection is more common than hepatitis $\mathrm{B}$ infection in maintenance hemodialysis patients. World $J$

Gastroenterol. 2008;14(14):2288-9.

DOI: 10.3748/wjg.14.2288.

19. Saxena AK, Panhotra BR. The vulnerability of middleaged and elderly patients to hepatitis $C$ virus infection in a high-prevalence hospital-based hemodialysis setting. $J$ Am Geriatr Soc. 2004;52(2):242-246.

DOI: $10.1111 / \mathrm{j} .1532-5415.2004 .52062 . x$

How to cite this article: Patil SS, Munjappa B, Gadgil SA. Gadve A. Prevalence of asymptomatic hepatitis B virus and hepatitis C virus infections in patients with maintenance hemodialysis of a tertiary care hospital in western Maharashtra. Indian J Microbiol Res. 2018;5(3):382-386. 